\title{
Subcellular localization of type I thionins in the endosperms of wheat and barley
}

\author{
Maria J. Carmona , C. Hernández-Lucas, Carmen San Martín , P. González, and F. Garcúa-Olmedo \\ Departmento de Bioquímica, E. T. S. Ingenieros Agrónomos, Universidad Politécnica de Madrid and Centro de Biologia Molecular, \\ Universidad Autónoma de Madrid, Madrid
}

\begin{abstract}
Summary. Thionins are cysteine-rich polypeptides of about 5,000 Da. Localization at the subcellular level of type I endosperm thionins has been carried out by immunogold labeling, using an antibody that recognizes type I thionin variants. In developing wheat and barley caryopses, sectioned at different times between 13 and 24 days after flowering, this type of thionins was only detected around protein bodies from cells of the starchy endosperm, using light microscopy. Electron microscopy revealed that these proteins were located in electron-dense spheroids in the periphery of protein bodies, at the earlier stages, whereas later the label appeared also as a thin layer around these organelles.
\end{abstract}

Keywords: Endosperm; Protein bodies; Thionins.

Abbreviations: DAF days after flowering; RER rough endoplasmic reticulum.

\section{Introduction}

In cereal caryopses, endosperm is a specialized tissue that is mobilized during germination to nourish the growing seedling and is the target for enzymes secreted by the aleurone layer and the scutellum. It contains starch granules and protein bodies, distinct organelles where storage proteins are located. This tissue also contains other types of abundant proteins, one of which is represented by the thionins, a protein family that has received considerable attention because of its toxicity towards plant pathogens and other heterologous systems (see García-Olmedo et al. 1989).

Thionins are cystein-rich polypeptides of about $5 \mathrm{kDa}$ that are also present in cereal leaves (Bohlman and Apel 1987, Gausing 1987) and in a wide range of plant species (García-Olmedo et al. 1989, 1992). Known thionin amino-acid sequences have been classified into five structural types, the first of which (type I) corresponds to the original thionins identified in the endosperms of wheat (Balls et al. 1942 a, b) and barley (Redman and Fisher 1969). One genetic variant per haploid genome $(\alpha 1, \alpha 2, \beta)$ in hexaploid wheat (Triticum aestivum) and two variants $(\alpha, \beta)$ in barley (Hordeum vulgare) have been found so far for type I thionins (Fernández de Caleya et al. 1976, Redman and Fischer 1969). Preliminary subcellular fractionation studies, carried out with developing and mature barley endosperm, suggested that type I thionins were associated with the endoplasmic reticulum and the protein bodies (Carbonero et al. 1989, Ponz etal. 1983), whereas type II thionins have been reported to be associated with cell walls and vacuoles in barley leaves (Bohlman et al. 1988, Reimann-Philipp et al. 1989). The only other thionin type in wheat and barley, type $V$, has only been characterized at the DNA level (Castagnaro et al. 1992) and no subcellular location studies have been carried out yet. We now report an immunolocalization study of type I thionins in wheat and barley endosperms which shows that these proteins are present in electrondense spheroids in the periphery of protein bodies.

\section{Materials and methods}

Plant material

Wheat (Tritictum aestioum L. cv. Chinese Spring) was obtained from E. R. Sears (Columbia, Mo.). The cultivated barley Hordeum vulgare L. cv. Bomi was the gift of H. Doll (Risø Laboratory, Denmark). Plants were grown under standard green house conditions. Developing seeds were harvested from plants at 13, 15, 17, 20, and 24 
days after flowering (DAF). Thionin variants purified by high-performance-liquid-chromatography (HPLC) were the gift of A. Molina (Madrid, Spain).

\section{Tissue preparation}

Transverse sections of grains ( $1 \mathrm{~mm}$ thick blocks) were fixed for $2 \mathrm{~h}$ at $4^{\circ} \mathrm{C}$ with $2.5 \%$ glutaraldehyde or $4 \%$ paraformaldehyde in $25 \mathrm{mM}$ $\mathrm{K}$-phosphate buffer, pH 7.2. The tissue was washed with three changes of excess phosphate buffer at $4^{\circ} \mathrm{C}$. The best results were obtained with seeds lixed in $4 \%$ paraformaldehyde. Samples were dehydrated in a graded ethanol series on ice: $5 \mathrm{~min}$ each in $10 \%$, $30 \%, 50 \%, 70 \%$, and $100 \%$ ethanol. After infiltration in $50 \%$ LR white resin in ethanol (Polysciences, Northampton, U.K.) for $(\mathrm{h}$, the samples were placed in $100 \%$ LR White resin for 3 days with changes. Polymerization was performed with fresh resin at $55^{\circ} \mathrm{C}$ for $24 \mathrm{~h}$.

Silver-colored thin sections were obtained with a glass knife and mounted on nickel grids coated with collodion and carbon ( $200 \mathrm{mesh}$; Vesco, Eerbeek. Holland) for electron microscopy. For light microscopy, I $\mu \mathrm{m}$-thick sections were extended on poly-L-lysine-coated slides.

Preparation of monospecific antibody and Western-blot procedure

Rabbit antiserum against purified $\beta$-thionin from barley had been previously raised (Ponz et al. 1983). Purification of antibody was accomplished by passage through a thionin-Sepharose affinity column according to Shapiro et al. (1974). Seeds were ground to a fine powder and extracted with $0.05 \mathrm{~N}_{2} \mathrm{SO}_{4}$ and protein precipitated with 9 volumes of acetone. Extracts from barley and wheat, as well as five purified variants of thionins, were subjected to sodium-dodecyl-sulphate electrophoresis (SDS.PAGE) on 4-20\% polyacrylamide-gradient gels, and to immunoblot analysis according to the manufacturers' instructions (BioRad, Richmond, Calif., U.S.A.).

\section{Immunacytochemical staining}

Ultrathin sections mounted on coated nickel grids were blocked with $1 \%$ ovalbumin in Tris-buffered saline (TBS; $20 \mathrm{mM}$ 2-amino-2-(hydroxymethyl)-1,3-propanediol (Tris)-HCl, pH 7.5 and $500 \mathrm{mM}$ $\mathrm{NaCl}$ for $10 \mathrm{~min}$ at room temperature. The grids were then incubated overnight at $4{ }^{\circ} \mathrm{C}$ with affinity-purified $\beta$-thionin-specific antibody in TBS with $1 \%$ ovalbumin. Controls were done in parallel using preimmune serum or TBS with $1 \%$ ovalbumin. Non-specifically bound antibodies were removed by washing the grids five times on a drop of TBS for $5 \mathrm{~min}$. The grids were then floated for $1 \mathrm{~h}$ on a drop of $10 \mathrm{~nm}$ diameter protein A-gold (Janssen Biotech, Olen, Belgium) diluted $1: 20$ in TBS-1\% ovalbumin. The incubation was followed by three washes with TBS and another three washes in distilled water. Grids were stained with a saturated uranyl acetate solution for $15 \mathrm{~min}$. The same protocol was followed for the $1 \mu \mathrm{m}$ thick sections for light microscopy, except the last step. After washing the second antibody, silver enhancement of colloidal-gold immunolabelling was performed, following the manufacturers' protocol (Janssen Biotech). A Jeol 1100 transmission electron microscope and a Nikon M-35S microscope were used.

\section{Results}

\section{Antibody specificity}

The specificity of an antibody raised against barley $\boldsymbol{\beta}$ thionin and purified by affinity chromatography on a

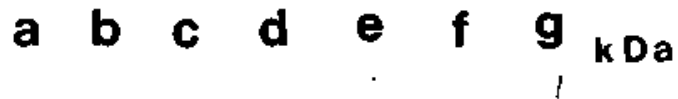

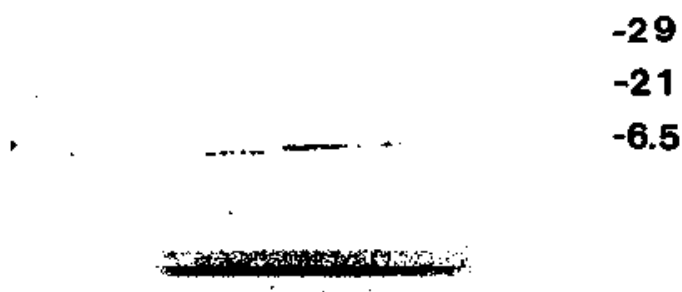

Fig. 1. Western blot analysis of the specificity of the $\boldsymbol{\beta}$-thionin antisetum. Protein extracts from the endosperms of barley $(a)$ and wheat (g). $b$ and $c \alpha$ - and $\beta$-thionins from barley; $\alpha-\gamma_{\alpha} 1, \alpha 2$, and $\beta$ thionins from wheat, respectively. After transfer to an immobilon membrane, the immunoreactive bands were visualized by incubation with protein A-gold and silver enhancement

thionin-Sepharose column (Ponz et al. 1983) was tested by Western-blot analysis of purified genetic variants and total protein extracts from wheat and barley (Fig. 1). All pure wheat and barley endosperm variants of type I thionin reacted with the antibody, and in total endosperm extracts, only the thionin band was recognized by it (Fig. 1). Thionins of types II and V do not react with these antibodies (not shown). The crossreactivity among type $I$ thionins is in agreement with their close sequence similarity.

\section{Immunolocalization of type I thionins under the light microscope}

Developing endosperms from wheat and barley were sectioned at different moments between 13 and 24 days after flowering (DAF) to localize thionins and to analyze their accumulation and deposition during development. This period was chosen because thionins had been previously shown to be synthesized during the first half of endosperm development, with a maximum concentration of messenger at 13-16 DAF (Ponz et al. 1983, Rodriguez-Palenzuela et al. 1988). Beyond $24 \mathrm{DAF}$, the tissue became very difficult to section because of the accumulation of starch granules, specially in the case of barley, where the cells were largely filledup with starch granules as early as 17 DAF (Fig. $2 \mathrm{~d}-$ f). In wheat, protein bodies of different sizes appeared either alone or forming clusters, which became larger and more numerous with time, while at least some 


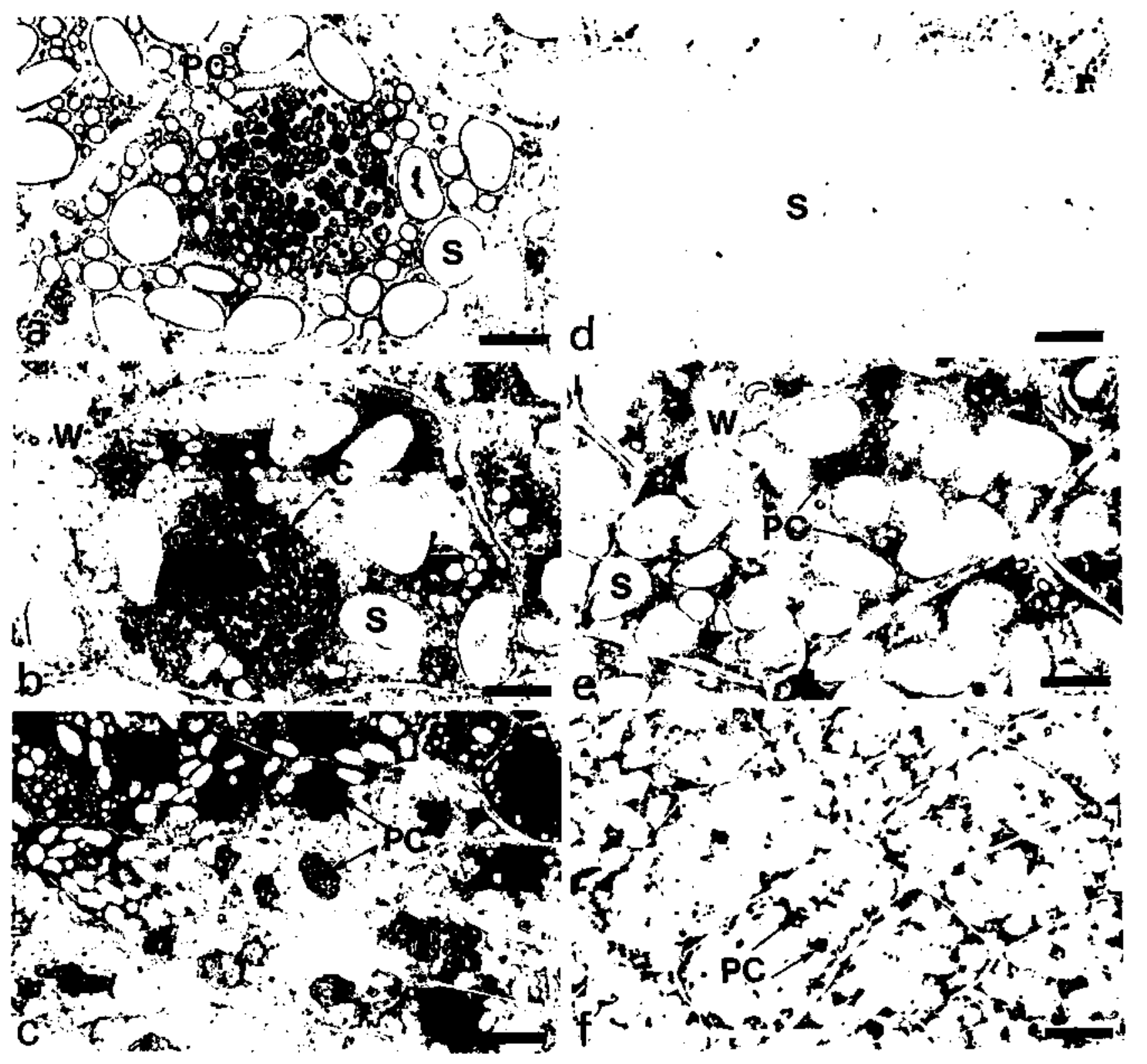

Fig. 2. Immunolocalization of wheat and barley thionins under the light microscope. Photographs correspond to a 24 DAF endosperm (wheat) and to a $17 \mathrm{DAF}$ endosperm (barley). $S$ Starch grain; $W$ cell wall; $P C$ protein body cluster. Bars: a, b, d, and e, $40 \mu \mathrm{m} ; \mathrm{c}$ and $\mathrm{f}, 100 \mu \mathrm{m}$. a Control section of wheat endosperm incubated with preimmune serum; $b$ wheat endosperm section treated with $\beta$-thionin antibody. Specific label was observed around protein-body clusters (PC); $\mathbf{c}$ low-magnification view of wheat section treated with $\beta$-thionin antibody. $d$ Control section of barley endosperm incubated with preimmune serum; $\mathbf{e}$ barley endosperm section incubated with $\beta$-thionin antibody. Intense labe] appeared around isolated protein bodies and small clusters; $f$ low-magnification view of barley section treated with $\beta$-thionin antibody

protein bodies seemed to fuse among each other (Fig. $2 \mathrm{a}-\mathrm{c}$ ). In barley, the process was similar, but the clusters were smaller and more scattered in the cell (Fig. $2 \mathrm{e}, \mathrm{f}$ ). Immunolabeling with the $\beta$-thionin-antibody/protein A-gold reagent showed staining around isolated protein bodies and protein-body clusters of starchy endosperm cells, both in wheat (Fig. 2 b, c) and in barley (Fig. $2 \mathrm{e}, \mathrm{f}$ ), with no labeling appearing in other cell structures or in cells from the aleurone and coat layers. No labeling was observed when preimmune serum was used (Fig. 2a, d).

\section{Electron-microscopic localization of type I thionins}

Electron microscopy of immunogold-labeled thin sections from wheat endosperms at the earlier stages of development (13 DAF) allowed the observation of gold particles specifically located in electron-dense spheroidal masses, which were normally associated with the 

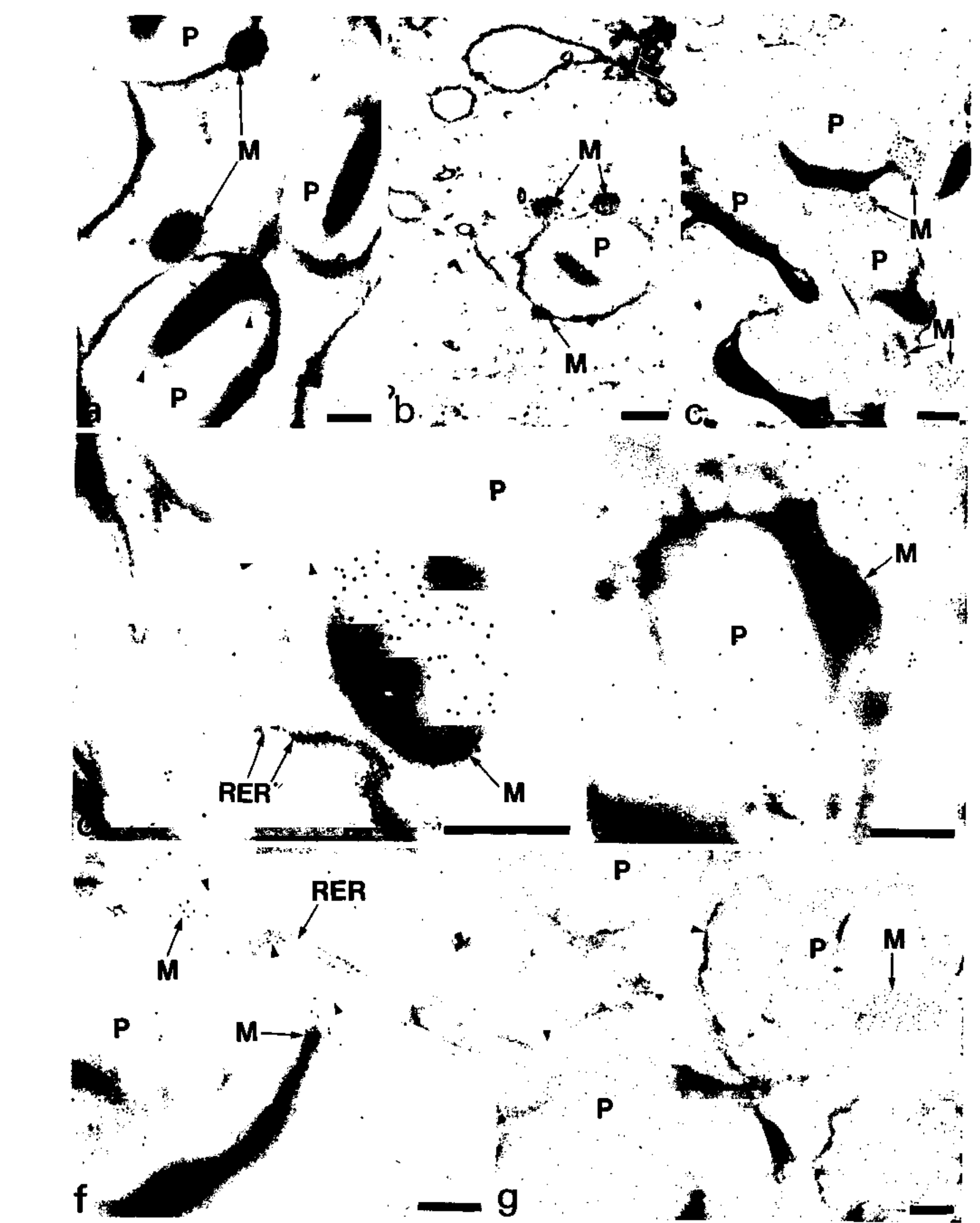


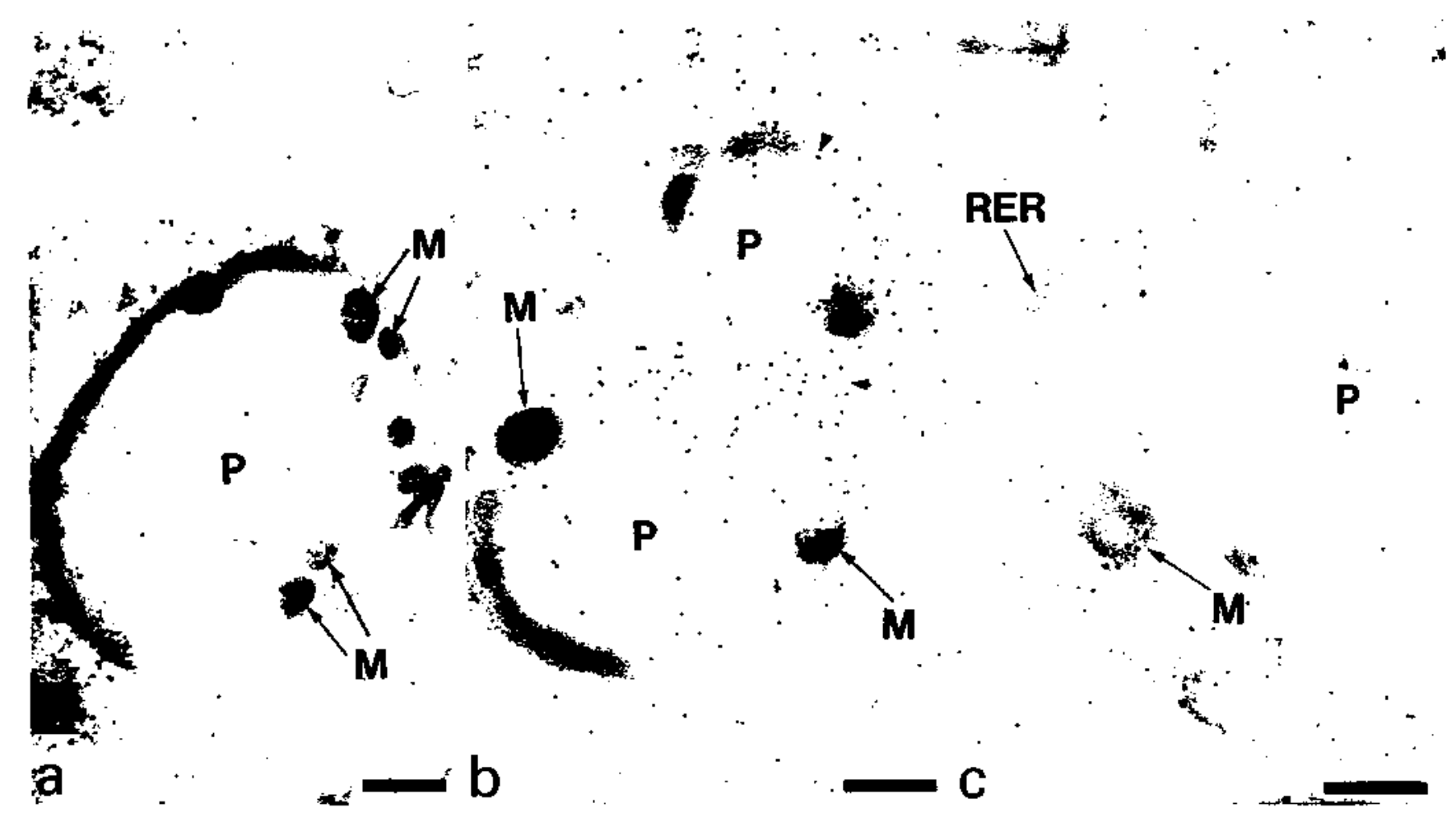

Fig. 4. Electron micrographs showing immunolocaliaztion of thionins in barley endosperm at 15 DAF. $M$ Spheroidal masses; $P$ protein body; $R E R$ rough endoplasmic reticulum. Bars: $0.5 \mu \mathrm{m}$. a Control section of endosperm incubated with preimmune serum; b section immunostained with $\beta$-thionin antibody. Label appeared in spheroidal masses and on the periphery of protein bodies (arrowheads); $\mathbf{c}$ labeled spheroidal mass localized in the vicinity of a protein body and surrounded by RER

periphery of both single and clustered protein bodies and only rarely appeared by themselves in their proximity (Fig. 3a-d). These masses appeared occasionally as flattened against the protein body surface (Fig. $3 \mathrm{e}$ ). The number and sizes of the spheroids varied among the different protein bodies. At later stages, they were less frequent and the gold label appeared not only in them, but throughout the membrane-like structure surrounding protein bodies (Fig. $3 \mathrm{~g}$ ). Similar observations were made in barley endosperm, where the number of spheroidal masses per protein body seemed to be greater (Fig. $4 \mathrm{a}-\mathrm{c}$ ).

Rough endoplasmic reticulum (RER) was always detected in the vicinity of the spheroidal masses, whether they were associated to the protein bodies or close to them (Figs. $3 \mathrm{~d}$, $\mathrm{f}$ and $4 \mathrm{c}$ ). No label was detected in other cellular membranes.

\section{Discussion}

The immunocytological data presented here show that endosperm thionins (type I) are located in the periphery of protein bodies. These observations suggest that thionins become integrated into the electron-dense spheroids in the surface of the protein bodies and that the spheroids eventually spread out as a layer around these organelles. Electron-dense spheroids associated with protein bodies have been previously described

Fig.3. Electron micrographs showing immunolocalization of thionins in wheat endosperm. RER Rough endosplasmic reticulum; $P$ protein body; $M$ spheroidal masses. Bars: $0.5 \mu \mathrm{m}$. a Control section incubated with preimmune serum (I3 DAF). Arrowheads point to background protein A-gold particles; b section immunostained with B-thionin antibody. Label appeared in spheroidal masses associated to the periphery of protein bodies, (13 DAF); $c$ a field of protein bodies which differ in the number and size of electron-dense spheroids (13 DAF); $d$ highmagnification view of electron-dense spheroid, protein body, and RER (13DAF). Note the connections between them (arrowheads); $e$ spheroidal mass spreading along the periphery of protein body (13 DAF); f micrograph showing RER, protein body membrane, and spheroidal masses (arrowheads) at $20 \mathrm{DAF} ; \mathrm{g}$ electron micrograph showing immunolocalization of thionin in wheat endosperm at $24 \mathrm{DAF}$. Intense label appeared on the surface of individual protein bodies of a cluster (arrowheads) 
both in barley (Munck and von Wettstein 1976, Cameron-Mills and von Wettstein 1980, Rasmussen et al. 1990) and in wheat (Buttrose 1963, Parker 1980, Campbell et al. 1981, Kim et al. 1988, Bechtel et al. 1989, Stenram etal. 1991). The wheat spheroids were not labeled by gliadin or glutelin antibodies (Kim et al. 1988, Stenram et al. 1991). However, Bechtel et al. (1989) have reported that these spheroids also contain triticin, a legumin-like protein. No such spheroids are present in leaf tissues, where it has been claimed that type II thionins are located in the cell wall (Bohlman et al. 1988) and in the vacuoles (Reimann-Philipp et al. 1989). As the synthesis of type I thionins appears to start and to level off somewhat earlier than the main reserve proteins (Ponz et al. 1983), the electron-dense spheroids could serve as transport and/or temporary storage structures from which the final deposition around the protein body would take place.

As it has been suggested that thionins could function as secondary thiol messengers in the redox regulation of enzyme activity and that they may cooperate in the rearrangement of disulphide bridges (Johnson et al. 1987), their location in the periphery of protein bodies allows to speculate that they may play a role either in packaging storage proteins into these organelles or in their mobilization during germination. In this context, it has been shown that the predominant proteases released by barley aleurone during germination, to mobilize the storage proteins, are cysteine proteases, whose proper conformation seems to be stabilized by disulphide bonds (Fincher 1989, Koehler and Ho 1990). Rearrangement of disulphide bonds has been specifically claimed in connection with protein-body growth in maize, where cysteine-rich proteins have been also identified in an electron-dense layer around protein bodies (Ludevild et al. 1984, Lending et al. 1988, Lending and Larkins 1989).

\section{Acknowledgements}

The authors are gratefully indebted to Drs. J. L. Carrascosa, U. Sonnewald, L. Willmitzer, and J. Orellana for helpful advice and discussion and to J. Garcia and D. Lamoneda for technical assistance.

\section{References}

Balls AK, Hale WS, Harris TH (1942 a) A crystalline protein obtained from a lipoprotein of wheat flour. Cereal Chem 19: 279288

- - - (1942 b) Further observations on a crystalline wheat pro. tein. Cereal Chem 19: 840-844

Bechtel DB, Wilson JD, Shewry PR (1989) Identification of leguminlike proteins in thin section of developing wheat endosperm by immunocytochemical procedures (abstract). Cereal Food World 34: 784

Bohlman H, Apel K (1987) lsolation and characterization of cDNAs coding for leaf-specific thionins closely related to the endospermspecific hordothionin of barley (Hordeum vulgare L.). Mol Gen Genet 207: 446-454

- Clausen S, Behnke S, Giese H, Hiller C, Reimann-Philipp V, Schrader G, Barkholt V, Apel K (1988) Leaf-specific thionins of barley - a novel class of ell wall proteins toxic to plantpathogenic fungi and possibly involved in the defence mechanism of plants. EMBO J 7: 1559-1565

Buttrose MS (1963) Ultrastructure of the developing wheat endosperm. Aust J Biol Sci 16: 305-317

Cameron-Mills V, von Wettstein D (1980) Protein body formation in the developing barley endosperm. Carlsberg Res Commun 45: 577-594

Campbell WP, Lee JW, O'Brien TP, Smart MG (1981) Endosperm morphology and protein body formation in developing wheat grain. Aust J Plant Physiol 8: 5-19

Carbonero P, Garcia-Olmedo F, Hernández-Lucas C (1980) External association of hordothionin with protein bodies in mature barley. J Agric Food Chem 28: 399-402

Castagnaro A, Maraña C, Carbonero P, Garcia-Olmedo F (1992) Extreme divergence of a novel wheat thionin generated by a mutational burst specifically affecting the mature protein domain of the precursor. J Mol Biol 224: 1003-1009

Fernández de Caleya R, Hernández-Lucas C, Carbonero P, GarcíaOlmedo F (1976) Gene expression in alloploids: genetic control of lipopurothionins in wheat. Genetics 83: 687-699

Fincher GB (1989) Molecular and celluar biology associated with endosperm mobilization in germinating cereal grains. Annu Rev Plant Physiol Plant Mol Biol 40: 305-346

García-Olmedo F, Rodriguez-Palenzuela P, Hemández-Lucas C, Ponz F, Maraña C, Carmona MJ, López-Fando J, Fernandez JA, Carbonero P (1989) The thionins: a protein family that includes purothionins, viscotoxins and crambins. In: Miflin BJ (ed) Oxford surveys of plant molecular and cell biology, vol 6. Oxford University Press, Oxford, pp $31-60$

- Carmona MJ, López-Fando JJ, Fernández JA, Castagnaro A, Molina A, Hernández-Lucas C, Carbonero P (1992) Characterization and analysis of thionin genes. In: Boller T, Meins $F$ (eds) Genes involved in plant defense. Springer, Wien New York, pp 283-302 [Dennis ES et al (eds) Plant gene research. Basic knowledge and application]

Gausing K (1987) Thionin genes specifically expressed in barley leaves. Planta 171: 24t-246

Johnson TC, Wada K, Buchanan BB. Holmgren A (1987) Reduction of purothionin by the wheat seed thioredoxin system. Plant Physiol 85: 446-451

Kim WT, Franceschi VR, Krishnan HB, Okita TW (1988) Formation of wheat protein bodies: involvement of the Golgi apparatus in gliadin transport. Planta 176: 173-182

Koehler SM, Ho THD (1990) Hormonal regulation, processing, and secretion of cysteine proteinases in barley aleurone layers. Plant Cell 2: 769-783

Lending CR, Larkins BA (1989) Changes in the zein composition of protein bodies during maize endosperm development. Plant Cell 1: 101 1-1023

- Kriz AL, Larkins BA, Bracker CE (1988) Structure of maize protein bodies and immunocytochemical localization of zeins. Protoplasma 143: 51-62 
Ludevild MD, Torrent M, Martinez-Izquierdo JA, Puigdomenech $P$, Palau $J$ (1984) Subcellular localization of glutelin-2 in majze (Zea mays L.) endosperm. Plant Mol Biol 3: 227-234

Munck L, von Wettstein D (1976) Effects of genes that change the amino acid composition of barley endosperm. In: Genetic improvement of seed proteins. National Academy of Sciences, Washington, DC, pp 71-82

Parker ML (1980) Protein body inclusions in developing wheat endosperm. Ann Bot 46: 29-36

Ponz F, Paz-Ares J, Hernández-Lucas C, Carbonero P, GarcíaOlmedo $F(1983)$ Synthesis and processing of thionin precursors in developing endosperm from barley (Hordeum vulgare L.). EMBO J 2: 1035-1040

Rasmussen U, Munck L, Ultrich S (1990) Immunogold localization of chymotrypsin inhibitor-2, a lysine-rich protein, in developing barley endosperm. Planta 180: 272-277
Redman DG, Fischer N (1969) Purothionin analogues from barley flour. J Sci Food Agric 20: 427-432

Reimann-Philipp U, Schrader G, Martinoia E, Barkholt V, Apel K (1989) Intracellular thionins of barley. J Biol Chem 264: 89788984

Rodríguez-Palenzuela P, Pintor-Toro JA, Carbonero P, Garcia-OImedo $F$ (1988) Nucleotide sequence and endosperm-specific expression of the structural gene for the toxin a-hordothionin in barley (Hordeum vulgare L.). Gene 70: 271-281

Shapiro DJ, Taylor JM, McKnight GS, Palacios R, Gonzalez C, Kiely ML, Schimke RT (1974) Isolation of hen oviduct ovalbumin and rat liver albumin polysomes by indirect immunoprecipitation. J Biol Chem 249: 3665-3671

Stenram U, Heneen WK, Skerrit J (1991) Immunocytochemical localization of wheat storage proteins in endosperm cells 30 days after anthesis. J Exp Bot 42: 1347-1355 